\title{
Monetary Policy Transmission Paths and Money Supply in Sub- Saharan Africa: Evidence from Nigeria and Ghana
}

Ugwuanyi Georgina Obinne: Department of Banking and Finance, College of Management Sciences, Michael Okpara University Agriculture, Umudike, Nigeria.

-Efanga Udeme Okon: Department of Banking and Finance, College of Management Sciences, Michael Okpara University Agriculture, Umudike, Nigeria.

Okanya Ogochukwu Chinelo: Department of Banking and Finance, Institute of Management and Technology, Enugu, Nigeria.

\begin{abstract}
The main objective of this study gears towards evaluating monetary policy transmission paths and money supply in Sub-Saharan Africa: evidence from Nigeria and Ghana from1981- 2018. The Central Bank of Nigeria, Bank of Ghana and World Bank, World Development Indicator of 2018 furnished us with the data used for analysis. This study explored three different monetary policy transmission channels: interest rate, credit and asset pricing transmission channels and these variables were regressed on money supply in both countries using Auto Regressive Distributed Lag (ARDL) Model estimation technique. The study also employed other diagnostic tests such as: Normality, Auto correlation test, Heteroskedasticity test and Breusch-Godfrey Serial Correlation LM test and they confirmed the validity and reliability of the model employed. The inferential results revealed that credit to private sector transmission channels in both Nigeria and Ghana had positive and significant impact on money supply but lending rate transmission paths in the two countries impacted insignificantly on money supply. This study concludes that monetary policy transmission channels in Nigeria were more robust in impacting on money supply than in Ghana. As such, the study recommends that monetary authorities of both countries need to formulate stringent monetary policies that will reduce the circulation of money outside the financial systems and there should be a synergy between monetary and fiscal policies in both economies so as to aid the instruments of macroeconomic policies achieve their objectives.
\end{abstract}

Key words: Monetary policies, Money supply, Transmission paths, Lending rate, Credit to private sector, Treasury bill rate.

International Journal of Business Management and Finance Research Vol. 4, No. 2, pp. 55-74

2021

DOI: $10.53935 / 26415313 . v 4 i 2.187$

Corresponding Author: Efanga Udeme Okon

Email:

Funding: This study received no specific

financial support.

Article History:

Received: 6 September 2021

Revised: 3 November 2021

Accepted: 22 November 202I

Published: 29 December 2021

(C) 2021 by the authors; licensee Academic

Publishing Group

\section{Introduction}

Monetary policy is a deliberate action of the central bank or appropriate monetary authorities of a country to regulate the availability of money in circulation using its array of monetary policy instruments such as interest rate, monetary policy rate, money supply and financial reserve ratio through various monetary policy transmission channels which include interest rate channel, exchange rate channel, monetary and credit aggregates channel and asset pricing channel in order to achieve price stability, low inflation rate, moderate cost of capital, economic stability amongst other macroeconomic objectives.

Monetary policy refers to the policy formulated by monetary authorities with regard to monetary (money) matters. It deals with the regulation and control of financial institutions, active purchases and sales of financial securities to affect changes in money supply and maintenance of interest rate (Jhingan, 2005). 
The classical theory of monetary policy postulates that changes in money supply or other aggregates will work through some intermediate variables through which some effects are transmitted to the ultimate goals of price stability, output, employment and external balance (Central Bank of Nigeria, 2011). Monetary policy transmission mechanism refers to the various intermediate channels through which changes in the nominal money stock or short term interest rates affect the macroeconomic aggregates. In Nigeria, Central bank of Nigerian Act 1969 empowered CBN with the monetary policy function under the supervision of Ministry of Finance (Central Bank of Nigeria, 2018).

Monetary policy can either be contractionary or expansionary. It is expansionary when the monetary authorities increase money supply within the economy with the aim of reducing cost of capital (interest rates). However, the authorities may choose to adopt a contractionary monetary policy if it wants to reduce the volume of money in circulation and cut money supply within the economy. Depending on the current state of the economy and what the authorities want to achieve, the authorities could either adopt a contractionary monetary policy or expansionary monetary policy to achieve its set target.

The monetary policy guidelines in both Nigeria and Ghana are being formulated, monitored and regulated by their respective Monetary Policy committees The Monetary Policy Committee (MPC) is responsible for formulating, monitoring and regulating the use and interaction of monetary policy instruments in their respective financial systems.

Monetary policy has a nexus with money supply in the sense that money supply is a target of monetary policy and the cardinal objective of monetary policy is the regulation of money supply to achieve economic stability and attainment of balance of payment equilibrium. As discussed in the preceding paragraph, the appropriate monetary authorities may either implement an expansionary monetary policy which borders on increment of money supply in the economy through the use of monetary policy instruments that impact on money supply such as; open market operations, statutory reserve requirements, interest rate amongst others or implement a contractionary monetary policy, which entails reducing the availability of money in circulation by reducing money supply through the use of the earlier mentioned monetary policy instruments to achieve this goal (Partachi \& Mija, 2015).

Ultimately the type of monetary policy adopted at any given time is dependent on the current state of the economy. The two possibilities are either the economy is experiencing inflation and price instability due to excess money supply in the economy or the economy is in a state of low money supply, which may result to under production and under employment due to the high cost of accessing borrowed funds. Whichever of the two circumstances presenting, authorities at any given time ought to be well equipped and ready with the appropriate monetary policy instruments designed to hit the targets through the various indicator variables that serve as transmission paths of monetary policy. However, for a policy to be at its optimal efficacy, there must be a moderate trade-off between expansionary and contractionary monetary policies in an economy in order to achieve economic stability and keep the economy running at its optimum.

This study is carried out to evaluate monetary policy transmission paths and money supply in SubSaharan Africa: evidence from Nigeria and Ghana. The research questions for this study include. What impact does interest rate transmission channel have on money supply to Nigeria and Ghana? How does asset pricing model transmission channel influence money supply to Nigeria and Ghana? To what extent does Credit Transmission channel impact on money supply to Nigeria and Ghana? ; And, How does the impact of monetary policy transmission paths on money supply in Nigeria compare with that of Ghana? The study is classified into five main sections: the introduction, review of related literature, the research methodology, data analysis and discussion of results, and finally, the conclusion and recommendations.

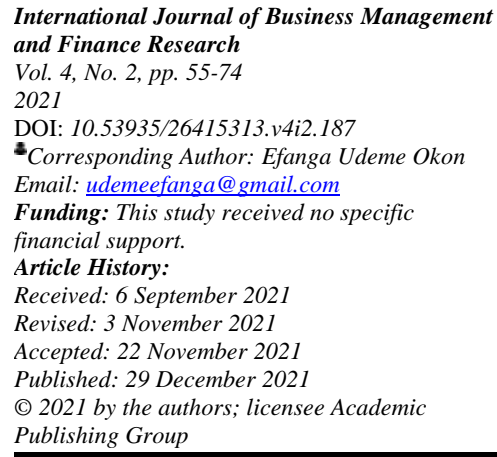

\subsection{Objectives of the Study}

The main objective of this research is to evaluate monetary policy transmission path and money supply in Sub- Saharan Africa: evidence from Nigeria and Ghana, while the specific objectives are to:

i. Ascertain the impact of interest rate transmission channel on money supply in both Nigeria and Ghana.

ii. Assess the influence of asset pricing model transmission channel on money supply to both Nigeria and. Ghana.

iii. Evaluate the extent to which credit transmission channel impacts on money supply in both Nigeria and Ghana. 
iv. Compare the impact of monetary policy transmission paths on money supply in Nigeria with that of Ghana.

\subsection{Hypotheses}

$\mathrm{HO}_{1}$ : Interest rate transmission channel does not have any significant impact on money supply in Nigeria and Ghana.

$\mathrm{HO}_{2}$ : There is no significant influence of asset pricing model transmission channel on money supply in Nigeria and Ghana.

$\mathrm{HO}_{3}$ : Credit transmission channel does not have any significant impact on money supply in Nigeria and Ghana.

\section{Literature Review}

\subsection{Conceptual Review}

According to FolaIwo and Osinubi (2006) monetary policy is a combination of various measures by a monetary authority to regulate and control the cost, value and availability of money in a country in line with current level of economic activities prevailing in the country.

The size and strength of monetary policy instruments or a combination of policy instruments to be deployed against target variables are determined by the size and structures of the related indicator variables themselves. For every macroeconomic goal, there is a target standing between the goal and the indicator variable and behind every indicator, there is an array of monetary policy instruments waiting to be activated. To get at the target, appropriate policy instruments have first to be directed at the relevant indicator variable. If the policy stance is to reduce the size and strength of the indicator variable upon which the size and the strength of the target depend, the authorities have to deploy appropriate monetary policy instruments capable of bringing down the size and strength of the indicator variable. Once the indicator variable has been successfully pruned down to size or vice versa, the related target variable will react sympathetically and in line with new position of the indicator variable (Onoh, 2007).

\subsection{Monetary Policy Instruments}

The instruments of monetary policy deployed by the Central Bank depend on the level of development of the economy, especially its financial sector. The commonly used instruments are discussed below:

Reserve Requirement: The Central Bank may require Commercial Banks to hold a fraction (or a combination) of their deposit liabilities (reserves) as vault cash and or deposits with it. Fractional reserve limits the amount of loans banks can make to the domestic economy and thus limits the supply of money. The assumption is that Commercial Banks generally maintain a stable relationship between their reserve holdings and the amount of credit they extend to the public. In other words, reserve requirement is the minimum reserve that is generally determined by the Central bank to be no less than the specified percentage of the amount of deposit liabilities that the commercial bank owes to its customers.

Open Market Operations: The open market operations refers to the sale and purchase of government securities and treasury bills by the Central bank of the country with a view to regulate the supply of money in the economy the Central Bank buys or sells ((on behalf of the Fiscal Authorities (the Treasury)) securities to the banking and non-banking public (that is in the open market). When the money in circulation is deemed high, the Central Bank sells securities (example government bonds, Treasury bills, etc) to reduce money supply and when it buys (back) securities-by redeeming them-it increases the supply of money to the Commercial Banks, thus affecting the volume of money in the economy.

Lending by the Central Bank: The Central Bank sometimes provide credit to Commercial Banks, thus affecting the level of reserves and hence the monetary base.

Interest Rate: The Central Bank lends to financially sound Commercial Banks at a most favourable rate of interest, called the minimum rediscount rate (MRR). The MRR sets the floor for the interest rate regime in the money market (the nominal anchor rate) and thereby affects the supply of credit, the supply of savings (which affects the supply of reserves and monetary aggregate) and the supply of investment (which affects full employment and GDP).

Direct Credit Control: The Central Bank can direct Commercial Banks on the maximum percentage or amount of loans (credit ceilings) to different economic sectors or activities, interest rate caps, liquid asset ratio

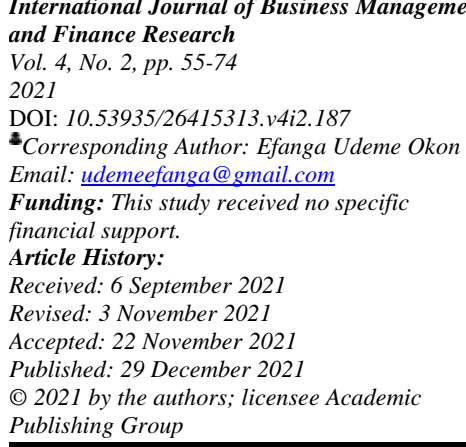


and issue credit guarantee to preferred loans. In this way the available savings is allocated and investment directed in particular directions.

Moral Suasion: The Central Bank issues licenses or operating permit to Commercial Banks and also regulates the operation of the banking system. It can, from this advantage, persuade banks to follow certain paths such as credit restraint or expansion, increased savings mobilization and promotion of exports through financial support, which otherwise they may not do, on the basis of their risk/return assessment.

Prudential Guidelines: The Central Bank may in writing require the Commercial Banks to exercise particular care in their operations in order that specified outcomes are realized. Key elements of prudential guidelines remove some discretion from bank management and replace it with rules in decision making.

Exchange Rate: The balance of payments can be in deficit or in surplus and each of these affect the monetary base, and hence the money supply in one direction or the other. By selling or buying foreign exchange, the Central Bank ensures that the exchange rate is at levels that do not affect domestic money supply in undesired direction, through the balance of payments and the real exchange rate. The real exchange rate when misaligned affects the current account balance because of its impact on external competitiveness. Moral suasion and prudential guidelines are direct supervision or qualitative instruments. The others are quantitative instruments because they have numerical benchmarks (Onoh, 2007).

\subsection{Transmission Path of Monetary Policies \\ 2.3.1. Interest Rate Transmission Mechanisms}

Interest rate transmission channel is the most conventional mechanism and at the same time, the one used in empirical studies to embody the joint effect of all the channels. It is the mechanism that underlies public intuition and media debates on the role played by monetary policy in modern economies. It combines the central bank's ability to affect a real variable (the interest rate) and the existence of inter-temporal substitution elasticity on the components of aggregate demand. In Nigerian financial market, the monetary authorities' control (direct or indirect) of the interest rates of other instruments can be large, thereby aiding the transmission of their policy decisions. The market can also interpret current interest rate movements as a signal of future monetary policy actions, making longer term rates react consistently.

\subsubsection{Credit Transmission Mechanisms}

The traditional transmission model rules out the existence of the financial sector, and every profitable project at the prevailing interest rate is undertaken as stated by Modigliani and Miller (1958) that the source of financing does not matter for the firm to make its (investment) decisions affirming that resources are always allocated efficiently. In a context of asymmetrical information and no transaction costs, financial intermediation serves no purpose and thus no resources are devoted to it. Nonetheless, financial intermediaries particularly banks exist as the economy's efficient response to information asymmetries between lenders and borrowers, its associated transaction and monitoring costs, and the presence of liquidity risks. Because financial intermediaries exist in a world with multiple financial instruments, at least two sources of financing must be recognized for firms. First, external or intermediated funds, where the firm accesses the financial market, but does not trade directly with individual investors, receiving their funds through an intermediary (bank loans). Secondly, the internal/direct funds, in which the firm either finances itself, without accessing the financial market, or is able to raise fund directly from individual investors (through the issue of bonds or stocks). For instance, an expansionary monetary policy that increases bank reserves and bank deposits increases the quantity of bank loans available. Where many borrowers are dependent on bank loans to finance their activities, this increase in bank loans will cause a rise in investment (and also consumer) spending, leading ultimately to an increase in aggregate output (Y) (Onwumere, Onodugo, \& Ibe, 2014).

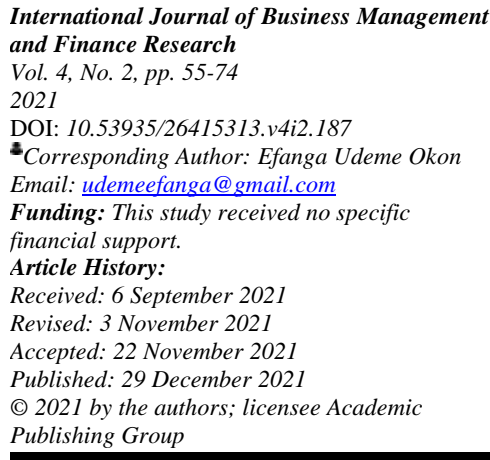

\subsubsection{Exchange Rate Transmission Mechanisms / Channel}

This channel is unique since it is the price of a particular financial asset, namely, another country's currency. However, because of its widespread impact as one of the economy's most important relative prices, and its direct effect on inflation through the prices of tradable goods, it is worth treating it as a separate channel. If the exchange rate is not fixed, its behavior should depend on the behavior of the domestic interest rate relative to the foreign rate. The exact impact of a change in the policy rate is uncertain, because it 
depends again on the expectations on the interest rates and on domestic and foreign inflation. However, ceteris paribus, an unexpected increase in the domestic interest rate appreciates the local currency as per impact. The exchange rate must move to a level where investors expect a sufficiently large future depreciation so that the expected returns of domestic and foreign deposits become equal. The result is an instant appreciation of the exchange rate. A contractionary monetary policy, leading to a currency appreciation, will reduce the imported component of inflation. The opposite process, the devaluation of the currency with an expansionary effect on exports and the overall level of activity, has been termed "competitive depreciation and has been traditionally advocated as a quick adjustment mechanism that prevents within a context of price stickiness a big rise in unemployment when facing an adverse shock. In practice, however, the uncovered interest parity, that underlies the expected relationship between domestic interest rate movements and exchange rate depreciation, has received scarce empirical support. The short-run behavior of the exchange rate appears to be extremely volatile, and expectations regarding its movements are closely related to the expected evolution of inflation (Onwumere et al., 2014).

\subsubsection{Asset Prices Channel}

The macroeconomic implications of asset prices have received a lot of attention from the academia, central banks and governments. For example, significant research efforts have been made to understand the roles of equity prices, house prices and other real estate prices in the transmission mechanism of monetary policy and macroeconomic stabilization at large. The concerns about these prices are both about whether monetary policy reinforces asset price inflation or asset prices development encourages less active monetary policy stabilization. As a result macroeconomists have suggested that monetary policy should respond systematically to asset prices and exchange rate developments. It means that changes in asset prices and exchange rates should be considered as part of the reaction function for central banks. Monetary policy expansion (decrease in the repo rate) affects the short-term money market rates and subsequently long term rates. These money market rate adjustments lower investment returns on domestic investment thus causing an outflow of financial capital and exchange rate depreciation. In addition, this expansions change banks and building society lending house prices and equity withdrawals. Asset prices such as stock prices and real estate prices lose their value affecting the economic activity as a whole.

\subsubsection{Monetary Policy in Nigeria}

Direct controls, pervasive government intervention in the financial system resulting in the stifling of competition and resource misallocation, necessitated the introduction of the Structural Adjustment Programme (SAP) in 1986. SAP was a comprehensive economic restructuring programme which emphasized increased reliance on market forces. In line with this orientation, financial sector reforms were initiated to enhance competition, reduce distortion in investment decisions and evolve a sound and more efficient financial system. The reforms which focused on structural changes, monetary policy, interest rate administration and foreign exchange management, encompass both financial market liberalization and institutional building in the financial sector. The broad objectives of financial sector reform include:

Removal of controls on interest rates to increase the level of savings and improve allocative efficiency; elimination of non-price rationing of credit to reduce misdirected credit and increase competition; adoption of indirect monetary management in place of the imposition of credit ceiling on individual banks; enhancing of institutional structure and supervision; strengthening the money and capital markets through policy changes and distress resolution measures; and improving the linkages between formal and informal financial sectors (Central Bank of Nigeria, 2018).

One of the objectives of financial reforms was to provide a liberalized and level playing field for the emergence of effective and efficient institutions that would serve as an engine of growth for the economy. Consequently, innovative institutions were encouraged to take advantage of the opportunities created by the financial liberalization policies. The structural changes in the financial sector were designed to increase competition, strengthen the supervisory role of the regulatory authorities and streamline public sector relationship with the financial sector. As part of the reform programme, the requirements for securing bank licenses were liberalized .Prior to 1986, Nigeria had only 40 banks, but the number increased progressively to 120 in 1992. By 1998, however, the number of banks in operation declined to 89 as a result of the liquidation of over 30 terminally distressed banks. Other types of financial institutions also increased substantially.




Indeed some of these institutions, such as the discount houses and Bureau De Change (BDC) were not in existence before 1986.Understanding the increased risk, the CBN directed the increase of Bank's capital base..For instance, the minimum capital requirements of banks stood at N500 million with effect from December 1998 compared with N10 million and N6 million for commercial and merchant banks in 1989 (Central Bank of Nigeria, 2018).

\subsubsection{New Products Development}

The reforms in financial sector created certain salutary effect on the financial system. The liberalization and the competition that it fostered led to new innovations and the development of new banking products. The use of modern technology enhanced service delivery and eliminated queues in banking halls which used to be the common feature of banks in Nigeria. The deployment of Automated Teller Machines (ATMs) at designated points across the country further reduced customer congestion in the banks for cash withdrawals and served to improve general customer experience. Indeed the overall effect was positive as service delivery was enhanced, queues eliminated and the use of debit and credit cards popularized by some banks to reduce the risk of carrying cash for transactions. Thus, the 1986 reform introduced e-money in Nigeria's banking lexicon.

\subsubsection{Shift in Monetary Policy Management}

It would be recalled that the direct approach to monetary management was the main technique of monetary policy implementation in Nigeria before the introduction of the Structural Adjustment Programme (SAP). Between 1986 and 1993, the CBN made efforts to create a new environment for the introduction of indirect approach to monetary management. A major action taken as part of the monetary reforms programme was the initial rationalization and eventual elimination of credit ceilings for selected banks that were adjudged to be sound. After the initial test run of the indirect monetary management approach, monetary management shifted to the indirect approach in which Open Market Operations (OMO) became the principal instrument of liquidity management. Since the introduction of the indirect approach, the primary and secondary markets for treasury securities have been developed to take advantage of liberalization introduced through the reforms. Discount houses, banks and recently some selected stockbrokers are now very active in the primary market for treasury bills (Central Bank of Nigeria, 2018).

\subsubsection{Interest Rate Regime}

In August, 1987 the CBN liberalized the interest rate regime and adopted the policy of fixing only its minimum rediscount rate to indicate the desired direction of interest rate. This was modified in 1989, when the CBN issued further directives on the required spreads between deposit and lending rates. In 1991, the government prescribed a maximum margin between each bank's average cost of funds and its maximum lending rates. Later, the $\mathrm{CBN}$ prescribed savings deposit rate and a maximum lending rate. Partial deregulation was, however, restored in 1992 when financial institutions were required to only maintain a specified spread between their average cost of funds and maximum lending rates. The removal of the maximum lending rate ceiling in 1993 saw interest rates rising to unprecedented levels in sympathy with rising inflation rate which rendered banks' high lending rates negative in real terms. In 1994, direct interest rate controls were restored. As these and other controls introduced in 1994 and 1995 had negative economic effects, total deregulation of interest rates was again adopted in October, 1996.

\subsubsection{The Payment System}

The Nigerian payments underwent substantial modernization with the implementation of the Magnetic Ink Character Recognition (MICR), which involved the phased adoption of MICR technology for processing of inter- bank transfer and in-house cheques. The introduction of Automated Teller Machine (ATMs) enhanced payments significantly. The ATMs in addition to cash dispensing, account balance enquiry, and enhancing payment of utility bills also provided the basis for setting up electronic links to on-line customers and other accounts systems among bank branch network to facilitate payments service. To further improve the efficiency of the payment system, the CBN in 2004 issued broad guidelines on electronic banking (ebanking). Thereby ensuring e-banking practices in Nigeria followed global best practices. Also, in order to encourage the use of electronic money (e-money), in line with international best practices, the Bank continues

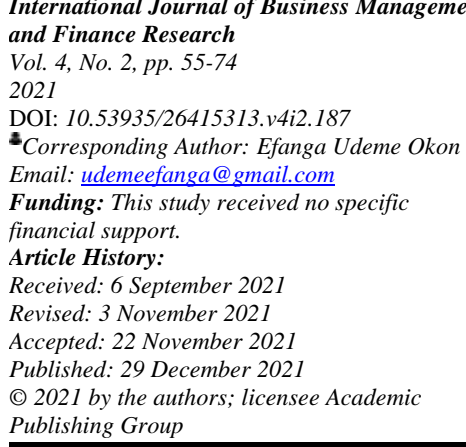


to issue specific guidelines on standards and use of e-money products such as credit cards, debit cards, digital cash, etc. With the recent revolution in the telecommunication sector, the environment for efficient e-banking service delivery had been laid.

Since then the CBN continues to promote the efficiency of the payment system, ; reduce cash transactions; and further enhance the transmission mechanism of monetary policy. In order to deal with largevalue payments and settlements, the CBN has embarked on the implementation of Real Time Gross Settlement (RTGS) system. The RTGS eliminates the risk in large-value payment, and increase the efficiency of the payment system (Central Bank of Nigeria, 2018).

\subsection{Foreign Exchange Management}

As part of the reforms, the foreign exchange market was liberalized with the reintroduction of the Dutch Auction System (DAS) in July 2002 with the objectives of realigning the exchange rate of the naira, conserving external reserves, enhancing market transparency and curbing capital flight from the country. Under this system, the Bank intervened twice weekly and end-users through authorized dealers bought foreign exchange at their bid rates. The rate that cleared the market (marginal rate) was adopted as the ruling rate exchange rate for the period, up to the next auction. DAS brought a good measure of stability in exchange rate as well a reduction in the arbitrage premium between the official and parallel market rates.

To further deregulate the foreign exchange market and also demystify access to Travelers Cheques (TCs) by end-users, Travelex Global and Financial Services and American Express (AMEX) commenced the direct sale of TCs to end-users in February 2002. The initiative, among others, was aimed at addressing some travelrelated problems associated with foreign exchange utilization. Specifically, the objectives were to: facilitate easy access to traveler's cheques by end-users; reduce the transaction cost to end-users of traveler's cheques; eliminate the use of spurious documents in obtaining TCs; reduce the gap between the official and parallel market exchange rates; and encourage the growth of bureau de change operations.

Other measures adopted to enhance the operational efficiency of the foreign exchange market included the unfettered access granted holders of ordinary domiciliary accounts to their funds, while utilization of funds in the non-oil export domiciliary accounts were permitted for eligible transactions. Furthermore, inward money transfers became payable in the currency of remittance. All oil and oil service companies were allowed to continue to sell their foreign exchange brought into the country to meet their local expenses to any bank of their choice, including the CBN. Procurement of foreign exchange for Business Travel Allowance (BTA) and Personal Travel Allowance (PTA) remained eligible in the foreign exchange market, subject to a maximum of US\$2,500.00 per quarter for BTA and US\$2,000.00 twice a year for PTA for beneficiaries above 12 years old. For travels to countries in the ECOWAS sub-region, BTA and PTA are issued in ECOWAS traveler's Cheques (Anonymous, n.d).

\subsection{Monetary Policy in Ghana}

In order to be effective and globally acceptable, monetary policies have to be dynamic. Thus, monetary policies have undergone dynamic changes globally but in African countries, this began in the 1980s and 1990s where there was a conscious move away from the direct control measures to indirect monetary policy. However, due to the absence and illiquidity of financial markets such as secondary bill markets, many countries were hardly employing indirect monetary control instruments such as open market operations (Ncube, 2007). In the specific case of Ghana, monetary policies have evolved from the use of direct instruments to the market-based approach where money supply is the target (Alexander, Enoch, \& Baliño, 1995; Roe \& Sowal, 1997). For instance, prior to the financial sector reforms in 1992, the Bank of Ghana (BoG) operated a system of managing money supply through direct controls and a fixed exchange rate system. While this approach was relatively easy to implement and also appealed to the government (which was mainly interested in channeling resources to certain "priority sectors" of the economy), there were several inefficiencies associated with its ability to give the right signals for allocating resources efficiently. As the reforms began, this system was abolished in favour of a relatively more market-based form of distributing and managing resources. Under the market-based system, the aim was to use indirect instruments to regulate money supply in order to achieve price stability and other economic objectives. This approach was based on the strong conviction that inflation in Ghana was solely or predominantly a monetary phenomenon, following 
the monetarist school of thought. Within this monetary policy framework, reserve money served as an operating target, money supply (M2+) as the intermediate target, with the final target being inflation.

Globally, as economies evolved, with corresponding deepening of the financial sector, several substitutes for money emerged, which rendered monetary targeting ineffective, particularly in the short run. Eventually, Ghana, along with other countries, abandoned the monetary targeting framework and adopted inflation targeting as a strategy for conducting monetary policy. In Ghana, the Bank of Ghana Act 2002 specifically considers the BoG as an inflation-targeting central bank by indicating in the BOG Act 617, Section 33(2) that:

"The Bank, in counteracting unusual movements in the money and prices in the country, shall use any of the instruments of control conferred upon it under this Act or under any other enactment to maintain and promote a balanced growth of the national economy"

The Bank of Ghana has since 2002 adopted a policy to stabilize price, maintain low inflation levels and fairly stable exchange rates (Abradu-Otoo, Amoah, \& Bawumia, 2003; Sowa \& Abradu-Otoo, 2007). Quartey (2010) noted that although the central bank has been pursuing low inflation policies since 2002it does not follow an explicit inflation targeting framework. However, the low inflation policy framework mimics an inflation targeting regime in which a specific level of inflation is set and targeted jointly by the central bank and the Ministry of Finance, but the target does not involve the usual modeling and minimizing of the loss functions as is typically done under inflation targeting regimes (Sowa \& Abradu-Otoo, 2007).

However, one thing that is evident is that although this "inflation targeting" framework has been operational since 2002; its outcome has not received much interest

Since 2000, Ghana's financial sector adopted a number of initiatives such as universal banking, enhancements of the Payment System, redenomination of the currency, to the Foreign Exchange Act (Act 723) and the new minimum paid-up capital of banks and non bank financial institutions, NBFIs). These initiatives have contributed to growth in the banking and non-banking financial subsectors of the economy in terms of their numbers and innovative products and services. In 1997, the financial sector of the country was made up of 17 banks and 33 NBFIs; by the end of 2012, this had increased to 29 banks and 53 NBFIs. These developments have also contributed to financial deepening, which is evident in the over 300 percent increase in the M2+/GDP ratio between 1997 and 2012.

There has been steady improvement in the inflation rates, especially in the last three years, enabling Ghana to achieve one of the West African Monetary Zone (WAMZ) convergence criteria of attaining singledigit inflation, albeit, briefly. However, given the direct relationship between inflation and interest rates, it is puzzling that interest rates, particularly lending rates while real saving rates were consitently negative from 1999 until recently.

Generally, while there have been remarkable improvements in monetary indicators (although some of them are very gradual) which suggest relatively effective monetary policies during the period under review, there is clearly the need for greater fiscal discipline given that monetary policies cannot achieve their intended purposes in the presence of fiscal imbalances. Thus, the government should continue to maintain a stable macroeconomic environment that ensures the monetary aggregates are within growth-optimizing limits. Secondly, despite the decline in policy rates and inflation rates during the period under review, lending rates remain high and this stifles private business. It is suggested that the new Bank of Ghana formula for computing the base rate of banks is strictly adhered to in order to ensure efficient and realistic charges on loans. In addition, proper address systems and the use of credit reference bureau should be highly encouraged to reduce the high loan default rate. Finally, government domestic borrowing from the banking system is severely affecting the cost of credit and crowding out the private sector and this should be curtailed.

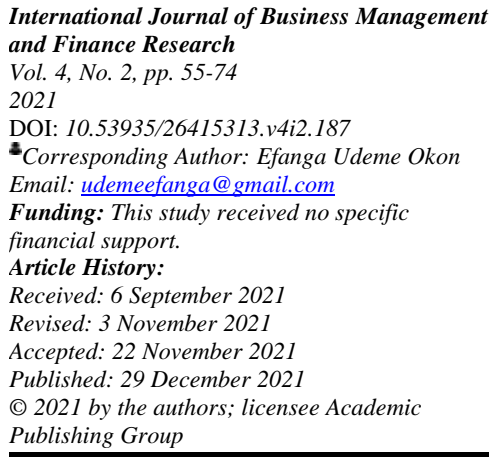

\subsection{Theoretical Framework}

Among the reviewed theories for this study, the following theory is seen to be noteworthy:

\subsection{Monetarist Theory}

The monetarist perspective was championed by Milton Friedman, closely aligns with the old quantity theory and opines that money has a significant role to play in an economy and further contends that money supply directly influences economic activities especially, the magnitude of income and price variables. While the old quantity suggested that an increase in money supply would bring about a direct proportionate increase in prices, the monetarists hold the view that the general price level determines the purchasing power (real 
money balances) a community will hold. If prices rise, a community's demand for real cash balances increases. The monetarist model is basically a demand for money model and not a money-supply model. The demand for money model of the monetarists is not intended to offer any explanations regarding changes in output, employment, money income or the price level, as does the Keynesian model. In the monetarists' demand for money model, money is regarded as an asset (wealth) with no yield, except implicit yield such as convenience and security, but which has to be treated like factors of production or commodities, its demand depends on total wealth, the prices and yields of monetary assets in terms of other substitute assets, tastes and preferences (Fu \& Liu, 2015).

As per theoretical underpinning, this study is anchored on the monetarist theory of money.

\subsection{Empirical Review}

Abradu-Otoo et al. (2003) employed the use of structural VECM using a seven variables system in analyzing the transmission mechanisms of monetary policy in Ghana. They found strong evidence suggesting a long run relationship between monetary policy and real economic variables. Monetary policy variables were very effective in influencing output and prices in the long run and that exchange rate channel was the most effective conduit through which the Central bank of Ghana transmits its policy to the economy. Similar results were obtained from Egypt by Mashat, Billmeier, and Fund (2008). They employed the use of VAR approach and discovered that exchange rate was the most effective channel in propagating monetary innovations to output and prices. However, they found other traditional channels, particularly the bank lending and asset price to be less effective and weaker channels just like they were found to be in other African countries. But the interest rate channel has been gaining momentum since 2005 when the interest corridor was introduced.

Mugume (2009) applied SVAR methodology in studying the Ugandan system and found that innovations in monetary policy influence inflation and economic activity but such influence was limited, as most of the important conventional channels were not functioning optimally. In particular, they found interest rate channel to be very weak and exchange rate channel and the credit channels were also not functioning at an expected level. Treasury bill rate remains the only effective channel that is partially operative but still indirectly through the lending rates.

Mishra, Das, and Mishra (2010) studied the dynamic relationship between savings and investment in India for the period 1950-51 to 2008-09 by employing Johansen co-integration technique and the Granger causality test via Vector Autoregressive framework. The authors found the presence of long run equilibrium relationship between savings and investments in India. The Granger causality test revealed directional causal relationship between the variables under study.

Lucky and Uzah (2017) examined the effects of monetary policy transmission mechanisms on the domestic real investment in Nigeria. Time series data were sourced from Central Bank of Nigerian statistical bulletin from 1981 to 2015. Domestic real investment was modeled as the function of percentage of credit to private sector to gross domestic product, naira exchange rate per US dollar, maximum lending rate, monetary policy rate, prime lending rate, net domestic credit, savings rate and Treasury bill rate. Granger causality test and Johansen co-integration test in the vector error correction model (VECM) setting were employed. Durbin Watson, $\beta$ Coefficient, R-Square (R2) and F-Statistics were used to determine the relationship between the dependent and independent variables as formulated in the regression models. The result proved that CPS/GDP, MLR, MPR, NDC and SR have positive relationship with Nigeria real domestic investment while EXR, PLR, and TBR have negative relationships with domestic real investment. The cointegration test proved the presence of a long run relationship between monetary policy variables and domestic real investment. The ADF test revealed that the variables are stationary at first difference, the granger causality test proved both bidirectional, uni-directional and independent relationships running from the independent variables to the dependent variable and from the dependent variable to the independent variables. The error correction model proved that the speed of adjustment is adequate while the parsimonious error correction model proved that MPR and SR have positive relationship while EXR and PLR have negative relationships. From the regression summary, the study concluded that monetary policy transmission mechanism has significant relationship with Nigeria domestic real investment.

Ezeaku, Ibe, Ugwuanyi , Modebe, and Agbaeze (2018) assessed the industry effects of monetary policy transmission channels in Nigeria within the period 1981-2014. Techniques of analysis employed in the study

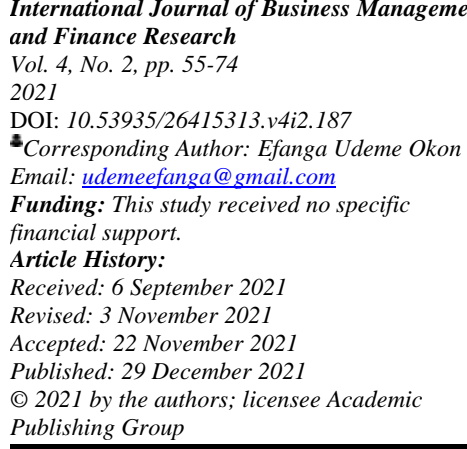




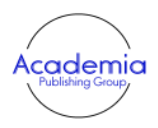

International Journal of Business Management and Finance Research Vol. 4. No. 2. pp. 55-74

2021

DOI: $10.53935 / 26415313 . v 4 i 2.187$

"Corresponding Author: Efanga Udeme Okon

Email: udeneefanga gang

Funding: This study received no specific

financial support.

Article History:

Received: 6 September 2021

Revised: 3 November 2021

Accepted: 22 November 202

Published: 29 December 2021

(C) 2021 by the authors; licensee Academic

Publishing Group were the Johansen cointegration and the error correction model (ECM). The regression estimates revealed that the private sector credit, interest rate, and exchange rate channels had negative effects on real output growth, both in the long and short run. The results further showed that, relatively, the degrees of the established effects were higher in the long run than in the short run. Johansen cointegration approach was used to determine the nature of relationship that exists between the dependent variable and the independent variables. The results showed that, in the Nigerian case, monetary policy transmission channels jointly had a long-run relationship with real output growth of the industrial sector, and disequilibrium in the system will be corrected at the speed of $72.2 \%$ annually.

Kovanen (2011) analyzed interest rate pass-through in Ghana. Time series and bank-specific data were utilized to highlight linkages between policies, wholesale market, and retail market interest rates. The analysis showed that responses to changes in the policy interest rate are gradual in the wholesale market. Prolonged deviation in the interbank interest rate from the prime rate illustrated the challenges the Bank of Ghana faces when targeting a short- term money market interest rate. Asymmetries in the wholesale market adjustment possibly relate to monetary policy signaling, weak policy credibility, and liquidity management. In the retail market, pass-through to deposit and lending interest rates is protracted and incomplete.

\section{Methodology}

\subsection{Research Design}

This study adopts the ex-post facto research design since it deals with event that had taken place and secondary data were readily available for collection. Money supply was employed as the regressand, while interest rate (lending rate), Treasury bill rate and ratio of credit to private sector to gross domestic product were employed as the regressors. The model was estimated using Auto Regressive Distributed (ARDL) Model. Since we are making use of annualized time-series data and the study cover a long sample period, we made sure our data set were not impaired by unit root; hence we tested for stationarity of the series by employing the Augmented Dickey-Fuller (ADF).

\subsection{Source of Data Collection}

Data for this study were extracted from Central Bank of Nigeria Statistical Bulletin of 2018, Central Bank of Ghana Statistical Bulletin of 2018 and World Bank, World Economic Indicator of 2018. The study period covers 1981 through 2018.

\subsection{Method of Data Analysis}

This study used descriptive statistics, unit root test, correlation, normality test and Auto Regressive Distributed (ARDL) Model in testing the hypotheses of the study. E-views 9.0 econometric statistical software package was used for the analysis.

\subsection{Model Specification}

This research adapted the economic model previously used by Lucky and Uzah (2017) that researched on Monetary Policy Transmission Mechanisms and Domestic Real Investment in Nigeria: A Time Series Study 1981- 2015. The mathematical model of this study, which had earlier been reviewed in the preceding section, is specified below:

DINVT $=\mathrm{f}(\mathrm{CPS} / \mathrm{GDP}$, EXR, MLR, MPR,PLR,NDC, SR,TBR $)$

Transforming Equation 3.1 above to econometric method, we have: $\mathrm{DINVT}=\beta_{0}+\beta_{1} \mathrm{CPS} / \mathrm{GDP}+\beta_{2} \mathrm{EXR}+\beta_{3} \mathrm{MLR}+\beta_{4} \mathrm{MPR}+\beta_{5} \mathrm{PLR}+\beta_{6} \mathrm{NDC}+\beta_{7} \mathrm{SR}+\beta_{8} \mathrm{TBR}+\mu$

\section{Where:}

DINVT= Domestic real investment proxy Gross Fixed Capital Formation to Gross Domestic Product CPS/GDP = Credit to private sector to Gross Domestic Product proxy for credit channel

$\mathrm{EXR}=$ Naira exchange rate per US Dollar proxy for exchange rate channel MLR $=$ Maximum lending rate proxy for interest rate channel

MPR $=$ Monetary policy rate proxy for interest rate channel PLR $=$ Prime lending rate proxy for interest rate channel NDC $=$ Net domestic credit proxy for credit channel

$\mathrm{SR}=$ Savings rate proxy for interest rate channel $\mathrm{TBR}=$ Treasury bill rate proxy for asset price channel $\mu=$ Error Term 
$\beta_{1}-\beta_{8}=$ Coefficient of Independent Variables to the Dependent Variable $\beta_{0}=$ Regression Intercept.

However, this study adapted the scholars' work by expunging MPR, PLR, NDC, EXR and SR while DINVT was replaced by money supply as the regressand. The above expunged variables were taken out from the adapted model so as not to over parametize the model and also check for muticollinearity as most of the variables were variants of some of the monetary policy channels. For instance, MPR, PLR and SR were all repeated proxy for interest rate while NDC was repeated proxy for credit channel. Money supply was factored in as the regresssand to capture the impact of monetary policy transmission path on money supply. In that regard, the regression model is specified thus:

LOGMSt $=\alpha_{0}+\alpha_{1}$ LOGCPS/GDPt $+\alpha_{2}$ LOGLRt $+\alpha_{3}$ LOGTBRt $+U_{t}$

Where:

MS = Money supply

CPS/GDP = Credit to private sector to gross Domestic Product, proxy for credit channel TBR $=$ Treasury bill rate, proxy for asset price channel

$\mathrm{LR}=$ Lending rate, proxy for interest rate channel $\mathrm{u}=$ Error term

$\alpha_{0}$ and $\alpha_{3}=$ Coefficients of their respective variables $\mathrm{t}=$ Time dimension

$\log =$ Natural $\log$

\subsection{Decision Rule}

The decision rule is we "fail to accept the null hypothesis" if the computed p-value is less than 5\% significant level. On the contrary, we "fail to reject the null hypothesis" if the computed p-value is higher than $5 \%$ significant level.

\subsection{A priori Expectation}

Based on the empirical review carried out, the followings are the expected results at the end of the analysis: Credit to private sector is expected to have a positive impact on money supply.

Treasury bill rate is expected to have a negative impact on money supply. Lending rate is expected to have a negative impact on money supply.

\begin{tabular}{lllll}
\hline Variables & \multicolumn{5}{c}{ Tuble-1. Unit Root Test. } \\
& Fuller test statistic & $\begin{array}{l}\text { Value } \\
\text { Vulity }\end{array}$ & $\begin{array}{l}\text { Critical } \\
\text { at 5\% }\end{array}$ & $\begin{array}{l}\text { value Integration } \\
\text { order/Inference }\end{array}$ \\
\hline M2 & -4.757827 & 0.0026 & -3.540328 & I $(1)$ \\
TBR & -3.024253 & 0.0418 & -2.943427 & I(0) \\
LR & -4.509729 & 0.0009 & -2.945842 & I $(1)$ \\
CPS/GDP & -4.876972 & 0.0003 & -2.945842 & I $(1)$ \\
\hline
\end{tabular}

\section{Data Analysis and Results Interpretation}

\subsection{A Case for the Nigerian Economy}

4.1.1. Pre-Estimation Test Result (Unit Root Test)

The unit root test results from Table 1 above shows that the integration order of the variables were mixture of I (1) and I(0). As such, the appropriate estimation technique to employ for analysis is the AutoRegressive Distributed Lag (ARDL) Model.

International Journal of Business Management and Finance Research Vol. 4. No. 2, pp. 55-74

DOI: $10.53935 / 26415313 . v 4 i 2.187$

Corresponding Author: Efanga Udeme Okon

Email: udemeefanga@gmail.com

Funding: This study received no specific

financial support.

Article History:

Received: 6 September 2021

Revised: 3 November 202

Accepted: 22 November 202

Published: 29 December 2021

(C) 2021 by the authors; licensee Academic

Publishing Group

\begin{tabular}{lllll} 
& \multicolumn{5}{c}{ Table-2. Correlation Matrix. } \\
\hline M2 & M2 & CPS/GDP & LR & TBR \\
CPS/GDP & 0.000000 & 0.910894 & 0.026842 & 0.183695 \\
LR & 0.026842 & 0.043004 & 0.043004 & 0.123827 \\
TBR & 0.183695 & 0.123827 & 0.488322 & 0.488322 \\
\hline
\end{tabular}




\subsubsection{Correlation Analysis}

From the result of correlation analysis in Table 2 above, all the independent variables recorded positive relationships with the dependent variable, and the variables had positive relationships amongst them

\begin{tabular}{lcccc}
\multicolumn{5}{c}{ Table-3. Descriptive Statistics. } \\
\hline & M2 & CPS/GDP & LR & TBR \\
\hline Mean & 5153.387 & 11.05262 & 17.12879 & 12.89412 \\
Median & 753.7047 & 8.209316 & 17.87170 & 12.72542 \\
Maximum & 25079.72 & 20.77330 & 24.77083 & 26.90000 \\
Minimum & 14.47117 & 5.917270 & 8.916667 & 4.500000 \\
Std. Dev. & 7536.495 & 5.377672 & 3.817500 & 4.847430 \\
Skewness & 1.337830 & 0.875430 & -0.772374 & 0.389602 \\
Kurtosis & 3.431295 & 1.962942 & 3.249451 & 3.240404 \\
Jarque-Bera & 11.62986 & 6.556586 & 3.876745 & 1.052842 \\
Probability & 0.002983 & 0.037693 & 0.143938 & 0.590715 \\
Sum & 195828.7 & 419.9995 & 650.8941 & 489.9767 \\
Sum Sq. Dev. & $2.10 \mathrm{E}+09$ & 1070.016 & 539.2124 & 869.4103 \\
Observations & 38 & 38 & 38 & 38 \\
\hline
\end{tabular}

\subsubsection{Descriptive Statistics}

The descriptive statistics presented in Table 3 shows that M2 has the highest mean value of 5153.387, followed by LR which has 17.12879, while TBR and CPS/GDP have 12.89412 and 11.05262 respectively. Note that the Mean describes the average value for each data series in the model. From the analysis, M2 has the highest Standard Deviation as it recorded 7536.495, implying that it is the most volatile variable in the model as it has the highest percentage of dispersion from the mean. Three variables, CPS/GDP, LR and TBR with $0.875430,0.772374$ and 0.389602 respectively, are skewed a little to the left, while M2 which has 1.337830 is skewed to the right.

The Peakedness as measured by Kurtosis reveals the following distributions: The distribution values of M2, LR, and TBR exceeded 3 which is the normal distribution hence, they are said to be leptokurtic having 3.431295, 3.24945and 3.240404, respectively. However, CPS/GDP has a value of 1.962942 which is less than 3 , thereby is platykurtic.

Jarque-Bera (JB) tests whether the series is normally distributed or not. The test statistic measures the difference of the skewness and kurtosis of the series with those from a normal distribution. In JB statistic, the null hypothesis which states that the distribution is normal is rejected at $5 \%$ level of significance. The LR has a Jarque-Bera statistic of 3.8 with a Probability of 0.14 while the TBR has a Jarque-bera of 1.0 with probability of 0.5 . They are as such accepted as being a normal distribution since its p-value is greater than $5 \%$ level of significance, while other variables are said to be not normally distributed.

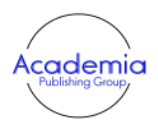

International Journal of Business Management and Finance Research

2021

DOI: $10.53935 / 26415313 . v 4 i 2.187$

"Corresponding Author: Efanga Udeme Okon Email: udemeefanga@gmail.com Funding: This study received no specific financial support.

Article History:

Received: 6 September 2021

Revised: 3 November 202

Accepted: 22 November 202

Published: 29 December 2021

(C) 2021 by the authors; licensee Academic

Publishing Group
Table-4. ARDL Model Result

\begin{tabular}{lllll}
\hline Variable & Coefficient & Std. Error & t-Statistic & Prob.* \\
\hline LOG(M2(-1)) & 0.777804 & 0.153059 & 5.081734 & 0.0000 \\
LOG(CPS/GDP) & 0.367860 & 0.089721 & 4.100041 & 0.0004 \\
LOG(TBR) & -0.117636 & 0.041274 & -2.850140 & 0.0091 \\
LOG(LR(-3)) & -0.106947 & 0.251018 & -0.426051 & 0.6740 \\
C & -2.112087 & 0.428383 & -4.930368 & 0.0001 \\
R-squared & 0.999268 & Mean dependent var & 6.984981 \\
Adjusted R-squared & 0.998950 & S.D. dependent var & 2.333827 \\
S.E. of regression & 0.075618 & Akaike info criterion & -2.070044 \\
Sum squared resid & 0.131517 & Schwarz criterion & -1.576222 \\
Log likelihood & 46.19075 & Hannan-Quinn criter. & -1.901636 \\
F-statistic & 3141.084 & Durbin-Watson stat & 1.936189 \\
Prob(F-statistic) & 0.000000 & & \\
\hline
\end{tabular}


Although these skewness and kurtosis indicate departure from normality, the descriptive statistics points are not strong enough to discredit the goodness of the dataset for the analysis in view. The number of observations of 38 depicts the duration of the study.

\subsubsection{ARDL Model Result}

From the ARDL Model result above in Table 4, the result revealed that the R-squared was 99\%, this means that the independent variables accounted for about $99 \%$ variations in the dependent variable while the remaining $1 \%$ may be attributed to variables not included in the model. Put differently, CPS/GDP, TBR and LR accounted for about $99 \%$ changes in M2, while the remaining $1 \%$ could be attributed to stochastic variables.

The result also revealed that CPS/GDP had a positive and significant impact on M2 such that a percentage increase in CPS/GDP would bring about a 0.36 percent increase in M2. TBR had a negative and significant impact on M2 such that a percentage increase in TBR would bring about a 0.11 percent decrease in M2. LR also recorded a negative and insignificant impact on M2 such that a percentage increase in LR would bring about a 0.10 percent decrease in M2.

The result further revealed that the overall model was a good fit owing to the f-statistic value of 3141.084 and its corresponding p-value of 0.000000 which shows that the model is significant at $5 \%$ level of significance. Durbin Watson Statistic of 1.9 established that the variables were free from auto-correlation since it is within the region of 2 .

Table-5. Test for Heteroskedasticity

\begin{tabular}{cccc}
\hline \multicolumn{4}{l}{ Heteroskedasticity Test: Breusch-Pagan-Godfrey } \\
\hline F-statistic & 2.043460 & Prob. F(10,23) & 0.0758 \\
Obs*R-squared & 15.99592 & Prob. Chi-Square(10) & 0.0997 \\
Scaled explained SS & 5.037448 & Prob. Chi-Square(10) & 0.8887 \\
\hline
\end{tabular}

\subsection{Diagnostic Test}

\subsubsection{Test for Heteroskedasticity}

The Heteroskedasticity test above suggests that the variables are free from the problem of Heteroskedasticity since the p-values of F-stat. and Obs*R-squared of 0.08 and 0.99 respectively are $>5 \%$ significance level. This outcome is further strengthened by the p-value of approximately 0.88 for the Scaled explained SS which also suggests the absence of Heteroskedasticity.

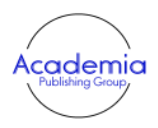

International Journal of Business Management and Finance Research

Vol. 4. No. 2, pp. 55-74

Vol. 4 .

DOI: $10.53935 / 26415313 . v 4 i 2.187$

Corresponding Author: Efanga Udeme Okon

Email: udemeefanga@gmail.com

Funding: This study received no specific

financial support.

Article History:

Received: 6 September 2021

Revised: 3 November 2021

Accepted: 22 November 202

Published: 29 December 2021

(C) 2021 by the authors; licensee Academic

Publishing Group

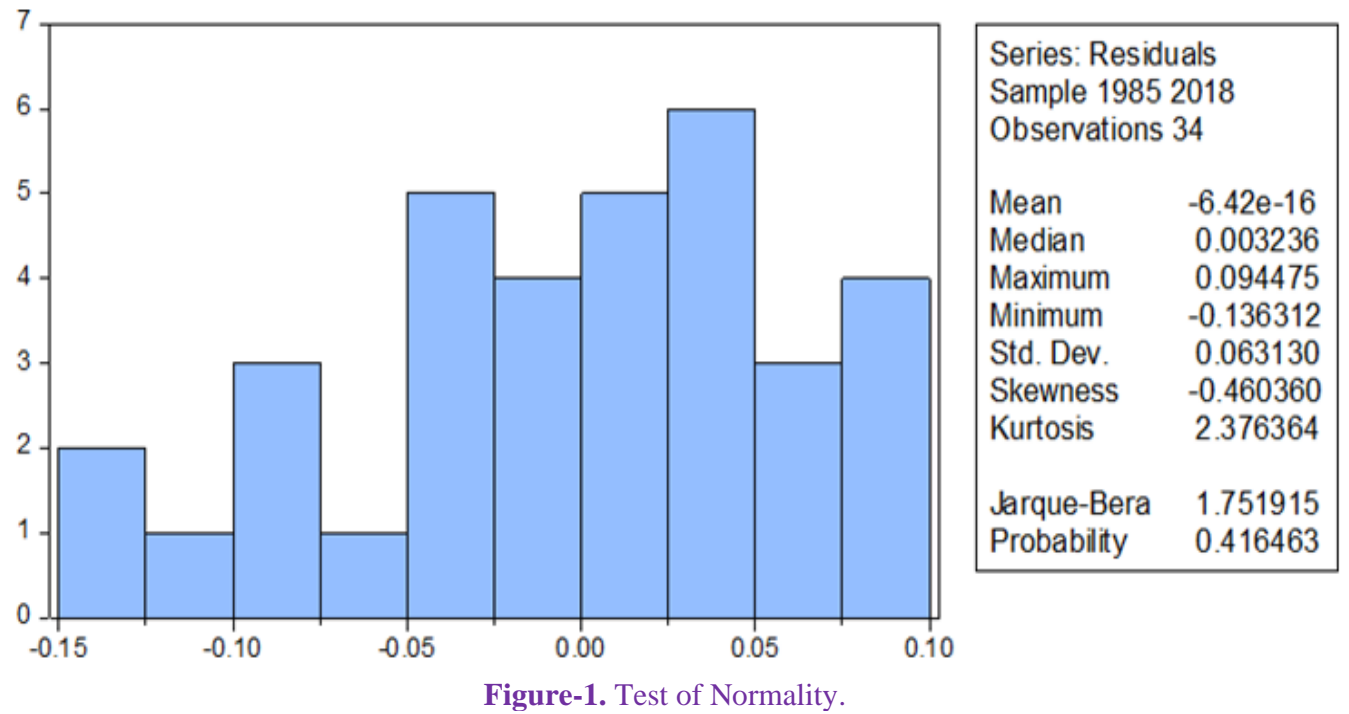


This test is conducted to ensure that the data employed in this study are normally distributed. Observing from the normality diagram in the figure above, as well as the Jarque-Bera value of 1.75 and its corresponding p-value of $42 \%$ which is $>5 \%$ significant level confirms that the data are normally distributed.

Table-6. Correlogram Q-statistic

\begin{tabular}{|c|c|c|c|c|c|c|}
\hline \multicolumn{7}{|c|}{ Q-statistic probabilities adjusted for 3 dynamic regressors } \\
\hline Autocorrelation & Partial Correlation & & $\mathbf{A C}$ & PAC & Q-Stat & Prob* \\
\hline & .1 & 1 & -0.011 & -0.011 & 0.0043 & 0.947 \\
\hline 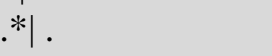 & $*$ & 2 & -0.072 & -0.072 & 0.2032 & 0.903 \\
\hline$* * \mid$. & $* * 1$ & 3 & -0.265 & -0.268 & 2.9700 & 0.396 \\
\hline$*$. & $*$ & 4 & -0.097 & -0.123 & 3.3522 & 0.501 \\
\hline$*$ & $* * \mid$ & 5 & -0.204 & -0.278 & 5.1018 & 0.404 \\
\hline$*$. & $* * \mid$ & 6 & -0.140 & -0.317 & 5.9534 & 0.428 \\
\hline. & .1 & 7 & 0.209 & 0.036 & 7.9321 & 0.339 \\
\hline $.1^{*}$. & .1 & 8 & 0.198 & 0.014 & 9.7697 & 0.282 \\
\hline & ** & 9 & 0.005 & -0.154 & 9.7711 & 0.369 \\
\hline .1 . & .1. & 10 & 0.006 & 0.000 & 9.7732 & 0.461 \\
\hline$*$ & .*1. & 11 & -0.127 & -0.175 & 10.635 & 0.474 \\
\hline 1. &.$* 1$. & 12 & -0.032 & -0.074 & 10.693 & 0.555 \\
\hline * $*$ & * & 13 & -0.146 & -0.112 & 11.928 & 0.534 \\
\hline .1. &.$* 1$. & 14 & -0.011 & -0.185 & 11.935 & 0.612 \\
\hline $\mid * *$ &.$\left.\right|^{*}$. & 15 & 0.227 & 0.100 & 15.267 & 0.432 \\
\hline . $*$ & . ${ }^{*}$ & 16 & 0.157 & 0.076 & 16.933 & 0.390 \\
\hline
\end{tabular}

\subsubsection{Test for Auto Correlation}

This test is carried out to further test for auto correlation and to consolidate on the result of Durbin Watson Stat in Table 4. The result of Correlogram Q-Statistic in Table 6 above, suggests that the variables are free from auto correlation, since the correlogram Q- Stat. table indicates that all p-values were $>5 \%$ hence, the conclusion that the model is free from auto correlation.

Table-7. Serial correlation

\begin{tabular}{cccc}
\hline Breusch-Godfrey Serial Correlation LM Test: & & \\
\hline F-statistic & 0.118464 & Prob. F(2,21) & 0.8889 \\
Obs*R-squared & 0.379317 & Prob. Chi-Square(2) & 0.8272 \\
\hline
\end{tabular}

\subsubsection{Test for Serial Correlation}

In line with the rule, the Breusch-Godfrey Serial Correlation LM Test table above shows that the probability value of 0.89 indicates that the variables are free from serial correlation. Also, F-statistic and Obs*R-squared of 0.12 and 0.38 respectively further strengthens the assertion of no serial correlation amongst the variables. The probability values are statistically insignificant at 5\% level of significance. Hence, the null hypothesis that there is serial correlation in the model is rejected. Thus, the model is said to be free from serial correlation.

International Journal of Business Management and Finance Research Vol. 4, No. 2, pp. $55-74$

Vol. 4 , $N$.

DOI: $10.53935 / 26415313 . v 4 i 2.187$

"Corresponding Author: Efanga Udeme Okon

Email: udemeefanga@gmail.com

Funding: This study received no specific

financial support.

Article History:

Received: 6 September 2021

Revised: 3 November 202

Accepted: 22 November 202

Published: 29 December 2021

() 2021 by the authors; licensee Academic Publishing Group
Table-8. Ramsey RESET Test.

\begin{tabular}{|c|c|c|c|}
\hline \multicolumn{4}{|c|}{ Equation: UNTITLED } \\
\hline \multicolumn{4}{|c|}{ Specification: LOG(M2) LOG(M2(-1)) LOG(M2(-2)) } \\
\hline \multicolumn{4}{|c|}{ LOG(M2(-3)) LOG(CPS/GDP) LOG(TBR) LOG(LR) } \\
\hline \multicolumn{4}{|c|}{ LOG(LR(-1)) LOG(LR(-2)) LOG(LR(-3)) LOG(LR(-4)) } \\
\hline \multicolumn{4}{|l|}{$\mathrm{C}$} \\
\hline \multicolumn{4}{|c|}{ Omitted Variables: Squares of fitted values } \\
\hline & Value & Df & Probability \\
\hline t-statistic & 1.391612 & 22 & 0.1780 \\
\hline F-statistic & 1.936584 & $(1,22)$ & 0.1780 \\
\hline
\end{tabular}




\subsubsection{Stability Diagnostic Test}

From the Ramsey reset test result in Table 8 above, the t-statistic of 1.4 and its corresponding p-value of 0.18 suggest that the model is correctly specified, so null hypothesis of linear specification not rejected at $5 \%$ level of significance, since the p-value is $<5 \%$.

\subsection{Test of Hypotheses}

4.3.1. Test of Hypothesis One

$\mathrm{H}_{1}$ : Interest rate transmission channel has no significant impact on money supply in Nigeria

Since the p-value for lending rate (LR) of $0.67(67 \%)$ is $>5 \%$ level of significance, the null hypothesis that interest rate transmission channel has no significant impact on money supply in Nigeria is not rejected. (See Table 4).

\subsubsection{Test of Hypothesis Two}

$\mathrm{HO}_{2}$ : There is no significant impact of asset pricing model transmission channel on money supply in Nigeria Since the p-value for treasury bill rate (TBR) of $0.009(0.9 \%)$ is within the acceptable significance level of $5 \%$, that is, $<5 \%$, we fail to accept the null hypothesis that there is no significant impact of asset pricing model transmission channel on money supply in Nigeria. (See Table 4). This means that it has a negative but significant impact on the money supply

\subsubsection{Test of Hypothesis Three}

$\mathrm{HO}_{3}$ : There is no significant impact of credit transmission channel on money supply in Nigeria.

Since the p-value for ratio of credit to private sector to gross domestic product (CPS/GDP) of 0.004 $(0.04 \%)$ is within the acceptable significance level of $5 \%$, that is, $<5 \%$. We then fail to accept the null hypothesis that there is no significant impact of credit transmission channel on money supply in Nigeria. (See Table 4).

Table-9. A priori Expectation for Nigeria.

\begin{tabular}{llll}
\hline Variables & Expected Signs & Actual Signs & Remark \\
\hline LOGTBR & Negative ( - ) & Negative ( - ) & Conform \\
LOG(CPS/GDP) & Positive ( + ) & Positive ( + ) & Conform \\
LOG(LR) & Negative ( - ) & Negative ( - ) & Conform \\
\hline
\end{tabular}

\begin{tabular}{lllll}
\multicolumn{7}{c}{ Table-10. Unit Root Test. } \\
\hline Variables & Augmented & $\begin{array}{l}\text { Probability } \\
\text { Value }\end{array}$ & $\begin{array}{l}\text { Critical } \\
\text { at 5\% }\end{array}$ & $\begin{array}{l}\text { value } \\
\text { Integration } \\
\text { order/Inference }\end{array}$ \\
\hline M2 & -3.415105 & 0.0189 & -2.971853 & $\mathrm{I}(0)$ \\
TBR & -4.611619 & 0.0007 & -2.943427 & $\mathrm{I}(0)$ \\
LR & -6.800433 & 0.0000 & -2.943427 & $\mathrm{I}(0)$ \\
CPS/GDP & -6.678263 & 0.0000 & -2.945842 & $\mathrm{I}(1)$ \\
\hline
\end{tabular}

\section{The Case for the Ghanaian Economy}

\subsection{Pre-Estimation Test Result (Unit Root Test)}

The unit root test results from Table 10 above shows that the integration order of the variables were mixture of I (1) and $\mathrm{I}(0)$. As such, the appropriate estimation technique to employ for analysis is the AutoRegressive Distributed Lag (ARDL) Model.

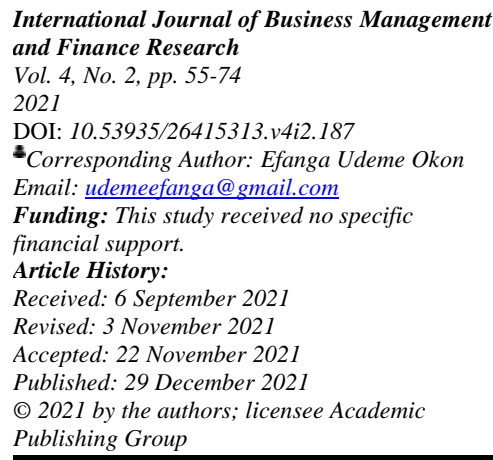

\begin{tabular}{lllll}
\multicolumn{5}{c}{ Table-11. Correlation Matrix. } \\
\hline M2 & M2 & CPSGDP & LR & TBR \\
CPSGDP & 1.000000 & -0.211508 & 0.062971 & 0.394127 \\
LR & -0.211508 & 1.000000 & 0.092398 & -0.122934 \\
TBR & 0.062971 & 0.092398 & 1.000000 & 0.235013 \\
\hline
\end{tabular}




\subsection{Correlation Analysis}

From the result of correlation analysis in Table 11 above, only CPSGDP has a negative relationship with the independent variable (M2) while the other independent variables, LR and TBR have positive relationships with M2.

\begin{tabular}{ccccc}
\multicolumn{5}{c}{ Table-12. Descriptive Statistics. } \\
\hline M2 & CPSGDP & TBR & LR \\
\hline Mean & 8238.793 & 6.628299 & 15.56891 & 15.73011 \\
Median & 464.0850 & 4.922454 & 14.17530 & 15.05105 \\
Maximum & 60426.76 & 33.61801 & 22.90000 & 21.70000 \\
Minimum & 11.30499 & 1.508572 & 11.30000 & 13.85730 \\
Std. Dev. & 15462.98 & 6.683097 & 3.316750 & 1.989323 \\
Skewness & 2.121767 & 2.554516 & 1.146913 & 1.327975 \\
Kurtosis & 6.514884 & 9.778839 & 2.884209 & 4.068784 \\
Jarque-Bera & 48.07315 & 114.0869 & 8.352160 & 12.97759 \\
Probability & 0.000000 & 0.000000 & 0.015359 & 0.001520 \\
Sum & 313074.1 & 251.8754 & 591.6187 & 597.7441 \\
Sum Sq. Dev. & $8.85 \mathrm{E}+09$ & 1652.560 & 407.0308 & 146.4240 \\
Observations & 38 & 38 & 38 & 38 \\
\hline
\end{tabular}

\subsection{Descriptive Statistics}

The descriptive statistics presented in Table 12 shows that M2 has the highest mean value of 8238.793, followed by LR which has 15.73011, while TBR and CPS/GDP have 15.56891and 6.628299 respectively. The Mean describes the average value for each data series in the model. From the analysis, M2 has the highest Standard Deviation as it recorded 15462.98, implying that it is the most volatile variable in the model as it has the highest percentage of dispersion from the mean. All the variables were skewed to the right since they all had values greater than 1 . Kurtosis a parameter used to measures the peakedness or flatness of the distribution of the series around the normal distribution (which suppose to be 3) .reveals that from Table 12 above, M2, LR and CPS/GDP are all having values that are above normal distribution with: 6.514884, 4.068784 and 9.778839 respectively, hence they are leptokurtic but TBR has a value (2.884209) that is less than 3 , and is said to be flat or platykurtic. Jarque-Bera (JB) tests whether the series is normally distributed or not. The test statistic measures the difference of the skewness and kurtosis of the series with those from a normal distribution. In JB statistic, the null hypothesis which states that the distribution is normal is rejected at 5\% level of significance. From the results of the analysis presented in Table 12 above, all the variables have probability values less than $5 \%$, therefore, it suffices to deduce that the variables were not normally distributed. Although skewness and kurtosis indicate departure from normality, these points are not strong enough to discredit the goodness of the dataset for the analysis in view. The number of observation of 38 depicts the duration of the study.

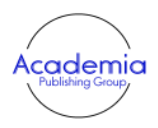

International Journal of Business Management and Finance Research Vol. 4. No 2 pp. 55-74

2021

DOI: $10.53935 / 26415313 . v 4 i 2.187$

DOI: $10.53935 / 26415313 . v 4 i 2.187$
"Corresponding Author: Efanga Udeme Okon Email: udemeefanga@gmail.com Funding: This study received no specific financial support.

Article History:

Received: 6 September 202I

Revised: 3 November 2021

Accepted: 22 November 202

Published: 29 December 2021

(C) 2021 by the authors; licensee Academic Publishing Group

Table-13. ARDL Result.

\begin{tabular}{lllll}
\hline Variable & Coefficient & Std. Error & t-Statistic & Prob.* \\
\hline LOG(M2(-1)) & 1.008557 & 0.026702 & 37.77085 & 0.0000 \\
LOG(CPS/GDP) & 0.398994 & 0.146880 & 2.716467 & 0.0107 \\
LOG(LR) & 0.437155 & 0.626855 & 0.697378 & 0.4908 \\
LOG(TBR) & 0.122792 & 0.410034 & 0.299469 & 0.7666 \\
C & -1.393002 & 1.893169 & -0.735804 & 0.4674 \\
R-squared & 0.986043 & Mean dependent var & 6.102049 \\
Adjusted R-squared & 0.983792 & S.D. dependent var & 3.133823 \\
S.E. of regression & 0.398971 & Akaike info criterion & 1.147537 \\
Sum squared resid & 4.934509 & Schwarz criterion & 1.408767 \\
Log likelihood & -15.22943 & Hannan-Quinn criter. & 1.239632 \\
F-statistic & 438.0211 & Durbin-Watson stat & 1.900957 \\
Prob(F-statistic) & 0.000000 & & \\
\hline
\end{tabular}




\subsection{ARDL Model Result}

From the ARDL Model result above in Table 13, the result revealed that the R-squared was $98 \%$, this means that the independent variables accounted for about $98 \%$ variations in the dependent variable while the remaining $2 \%$ may be attributed to variables not included in the model. Put differently, CPS/GDP, TBR and LR accounted for about $98 \%$ changes in M2, while the remaining $2 \%$ could be attributed to stochastic variables.

The result revealed that CPS/GDP had a positive and significant impact on M2 such that a percentage increase in CPS/GDP would bring about a 0.39 percent increase in M2. TBR had a positive and insignificant impact on M2 such that a percentage increase in TBR would bring about a 0.12 percent increase in M2. LR also recorded a positive and insignificant impact on M2 such that a percentage increase in LR would bring about a 0.43 percent increase in M2.

The result further revealed that the overall model was a good fit owing to the f-statistic value of 438.02 and its corresponding p-value of 0.000000 which shows that the model is significant at $5 \%$ level of significance. Durbin Watson Statistic of 1.9 showed that the variables were free from auto-correlation since it is within the region of 2 .

Table-14. Test for Heteroskedasticity.

\begin{tabular}{cccc}
\hline \multicolumn{4}{l}{ Heteroskedasticity Test: Breusch-Pagan-Godfrey } \\
\hline F-statistic & 4.263889 & Prob. F(5,31) & 0.0046 \\
Obs*R-squared & 15.07698 & Prob. Chi-Square(5) & 0.0100 \\
Scaled explained SS & 84.66597 & Prob. Chi-Square(5) & 0.0000 \\
\hline
\end{tabular}

\subsection{Diagnostic Test}

The Heteroskedasticity test above suggests that the variables are free from the problem of Heteroskedasticity since the p-values of F-stat. and Obs*R-squared of 0.005 and 0.01 respectively are within $5 \%$ significance level. This outcome is further strengthened by the p-value of approximately 0.00 for the Scaled explained SS which also suggest the absence of Heteroskedasticity.

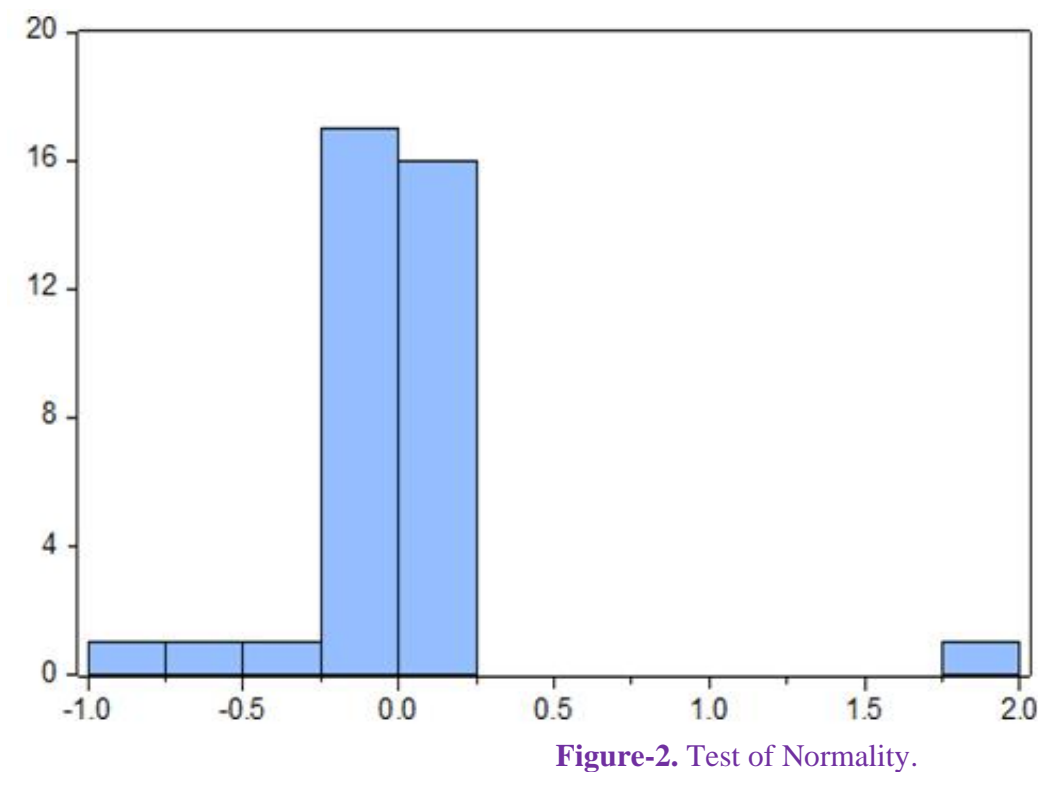

\begin{tabular}{|lr|}
\hline \multicolumn{2}{|l|}{ Series: Residuals } \\
Sample 1982 2018 \\
Observations 37 \\
Mean & $-4.71 \mathrm{e}-16$ \\
Median & -0.013442 \\
Maximum & 1.801140 \\
Minimum & -0.835201 \\
Std. Dev. & 0.370229 \\
Skewness & 2.769789 \\
Kurtosis & 16.99943 \\
& \\
Jarque-Bera & 349.4510 \\
Probability & 0.000000 \\
\hline
\end{tabular}
and Finance Research

Vol. 4 ,

DOI: $10.53935 / 26415313 . v 4 i 2.187$

Corresponding Author: Efanga Udeme Okon

Email: udemeefanga@gmail.com

Funding: This study received no specific

financial support.

Article History:

Received: 6 September 2021

Revised: 3 November 2021

Accepted: 22 November 202

Published: 29 December 2021

(C) 2021 by the authors; licensee Academic

Publishing Group

This test is conducted to ensure that the data employed in this study are normally distributed. Observing from the normality diagram in the Figure 2. above, as well as the Jarque-Bera value of 349.5 and its corresponding p-value of 0.000 which is $<5 \%$ significant level, one confirms that the data are not normally distributed. 
Table-15. Correlogram Q-statistic.

\begin{tabular}{|c|c|c|c|c|c|c|}
\hline \multicolumn{7}{|c|}{ Q-statistic probabilities adjusted for 1 dynamic regressor } \\
\hline.$||$. & .1 & 1 & 0.046 & 0.046 & 0.0857 & 0.770 \\
\hline$*{ }^{*}$. & .*. & 2 & -0.109 & -0.112 & 0.5769 & 0.749 \\
\hline.$||$. & .1. & 3 & 0.012 & 0.023 & 0.5830 & 0.900 \\
\hline .*1. &.$* 1$. & 4 & -0.081 & -0.096 & 0.8693 & 0.929 \\
\hline$* * \mid$. & $* * \mid$ & 5 & -0.260 & -0.253 & 3.9290 & 0.560 \\
\hline .1. & .1. & 6 & -0.020 & -0.021 & 3.9486 & 0.684 \\
\hline .1 .1 & .1. & 7 & 0.045 & -0.013 & 4.0441 & 0.775 \\
\hline. $\mid *$ &.$\left.\right|^{*}$ & 8 & 0.079 & 0.076 & 4.3563 & 0.824 \\
\hline.$\left.\right|^{*}$. &.$\left.\right|^{*}$. & 9 & 0.119 & 0.084 & 5.0852 & 0.827 \\
\hline .1. & * & 10 & -0.046 & -0.113 & 5.1964 & 0.878 \\
\hline .1 .1 & .1. & 11 & 0.011 & 0.034 & 5.2037 & 0.921 \\
\hline .1 .1 & .1 .1 & 12 & -0.043 & -0.049 & 5.3101 & 0.947 \\
\hline$. * \mid$ &.$||$. & 13 & -0.081 & -0.022 & 5.7077 & 0.956 \\
\hline$.\left.\right|^{*} . \mid$ &.$|*|$. & 14 & 0.079 & 0.134 & 6.0998 & 0.964 \\
\hline .1 .1 & .1 .1 & 15 & 0.005 & -0.059 & 6.1016 & 0.978 \\
\hline **1. & *.| & 16 & -0.196 & -0.200 & 8.7427 & 0.924 \\
\hline
\end{tabular}

\subsection{Test for Auto Correlation}

This test is carried out to check further for auto correlation and to consolidate on the result of Durbin Watson Stat in Table 12 The result of Correlogram Q-Statistic in Table 15 above, suggests that the variables are free from auto correlation, since the correlogram Q- Stat.table indicates that all p-values were $>5 \%$ hence, the conclusion that the model is free from auto correlation.

Table-16. Serial Correlation

\begin{tabular}{cccc}
\hline \multicolumn{5}{c}{ Bable-16. Serial Correlation. } \\
\hline F-statistic & 0.229378 & Prob. F(2,29) & 0.7965 \\
Obs*R-squared & 0.576194 & Prob. Chi-Square(2) & 0.7497 \\
\hline
\end{tabular}

\subsection{Test for Serial Correlation}

In line with the rule, the Breusch-Godfrey Serial Correlation LM Test in Table 16 above shows that the probability value of 0.79 indicates that the variables are free from serial correlation. Also, F-statistic and Obs*R- squared of 0.22 and 0.57 respectively further strengthen the assertion of no serial correlation amongst the variables. The probability values are statistically insignificant at $5 \%$ level of significance. Hence, the null hypothesis that there is serial correlation in the model is rejected. Thus, the model is said to be free from serial correlation.

\subsection{Stability Diagnostic Test}

Table-17. Ramsey RESET Test.

International Journal of Business Management and Finance Research

2021

DOI: $10.53935 / 26415313 . v 42.187$

Corresponding Author: Efanga Udeme Okon

Email: udemeefanga@gmail.com

Funding: This study received no specific

financial support.

Article History:

Received: 6 September 202I

Revised: 3 November 202I

Accepted: 22 November 202

Published: 29 December 2021

(C) 2021 by the authors; licensee Academic

Publishing Group

\begin{tabular}{|c|c|c|c|}
\hline \multicolumn{4}{|c|}{$\begin{array}{l}\text { Ramsey RESET Test } \\
\text { Equation: UNTITLED }\end{array}$} \\
\hline \multicolumn{4}{|c|}{ Specification: LOG(M2) LOG(M2(-1)) LOG(CPS/GDP) } \\
\hline \multicolumn{4}{|c|}{ LOG(CPS/GDP(-1)) LOG(LR) LOG(TBR) C } \\
\hline \multicolumn{4}{|c|}{ Omitted Variables: Squares of fitted values } \\
\hline & Value & Df & Probability \\
\hline t-statistic & 1.145658 & 30 & 0.2610 \\
\hline F-statistic & 1.312531 & $(1.30)$ & 0.2610 \\
\hline
\end{tabular}


5.9. Test of Hypotheses

5.9.1. Test of Hypothesis One

$\mathrm{HO}_{1}$ : Interest rate transmission channel has no significant impact on money supply in Ghana.

Since the p-value for lending rate (LR) of 0.4908 (49\%) is $>5 \%$ level of significance, the null hypothesis that interest rate transmission channel has no significant impact on money supply in Nigeria is not rejected. (See Table 13).

\subsection{Test of Hypothesis Two}

$\mathrm{HO}_{2}$ : There is no significant influence of asset pricing model transmission channel on money supply in Ghana.

Since the p-value for Treasury bill rate (TBR) of $0.7666(76 \%)$ is $>5 \%$ level of significance, the null hypothesis that asset pricing model transmission channel has no significant influence on money supply in Ghana is not rejected. (See Table 13).

\subsubsection{Test of Hypothesis Three}

$\mathrm{HO}_{3}$ : There is no significant impact of credit transmission channel on money supply in Ghana.

Since the p-value for ratio of credit to private sector to gross domestic product (CPS/GDP) of 0.0107 $(0.01 \%)$ is within the acceptable significance level of $5 \%$, that is, $<5 \%$, we fail to accept the null hypothesis that there is no significant impact of credit transmission channel on money supply in Ghana. (See Table 13).

\begin{tabular}{cccc}
\multicolumn{4}{c}{ Table-18. A priori Expectation for Ghana } \\
\hline Variables & Expected Signs & Actual Signs & Remark \\
\hline LOGTBR & Negative $(-)$ & Positive $(+)$ & Do not Conform \\
LOG(CPS/GDP) & Positive $(+)$ & Positive $(+)$ & Conform \\
LOG(LR) & Negative $(-)$ & Positive $(+)$ & Do not Conform \\
\hline
\end{tabular}

\section{Discussion of Findings}

The result of data analysis obtained in the previous section is classified into two major sections. The first section analyzed monetary policy transmission paths' impact on money supply in Nigeria, while the second segment looked at the transmission paths of monetary policy and their impact on money supply in Ghana.

\subsection{Comparing the Impact of Monetary Policy Transmission Paths on Money Supply in Nigeria with That of Ghana Focusing on Table 4, Table 9 (for Nigeria) and Table 13, Table 18 (for Ghana)}

In the Nigerian scenario, the results revealed that asset prices transmission channel was negatively but significantly impacting on money supply. While the interest rate transmission channel was observed to be negatively and insignificantly impacting on money supply in Nigeria. Additionally, all the monetary policy transmission channels in Nigeria within the period under study conformed to economic a priori expectations such that lending rate and Treasury bill rate representing interest rate and asset prices transmission channel, respectively, recorded an inverse relationship with money supply. For the credit to private sector representing credit transmission channel, it recorded a positive impact on money supply.

In Ghana's case, the results revealed that only the credit to private sector transmission channel of monetary policy was positively and significantly impacting on money supply, while the lending rate and asset prices transmission paths though positive as well were not found to be significant Our a priori expectations had been a positive and significant impact of all three variables on money supply, we however found that only the credit transmission channel of money supply in Ghana conformed with the lending rate but asset prices channels not conforming.

In comparative terms, judging from the results obtained from the analysis of both economies, it could be deduced that monetary policy transmission paths in Nigeria were more effective in regulating money supply than Ghana.

\section{Conclusion and Recommendation}

Based on the analysis and discussions so far in this study, the researchers therefore conclude that in Nigeria, monetary policy transmission channels within the period under review were more effective in regulating money supply than in Ghana. 


\section{Recommendations}

With regard to the data analysis conducted on monetary policy transmission paths and money supply in Nigeria and Ghana, the study proffers the following recommendations:

1. Monetary authorities of both countries should continue to maintain the current regulations and policies placed on credit transmission channel of monetary policy as it did not only impact on money supply significantly but also made credit channel of monetary policy conform to economic a priori expectation.

2. There should be a synergy between monetary and fiscal policies in both economies so as to aid the instruments of macroeconomic policies achieve its objectives. In Nigeria, the asset pricing transmission channel yielded significant impact on money supply and also supported economic expectation. But in Ghana, this was not the case. The Ghanaian monetary authorities should harness and consolidate monetary and fiscal policies to work in tandem and not divergent policies where the bank of Ghana increases Treasury bill rate in a bid to reduce money supply while an expansionary fiscal policy is in place.

3. With regard to lending rate, appropriate monetary authorities of both countries need to formulate stringent monetary policies that seek to markedly reduce the volume of money not accounted for within both financial systems. The volume of money outside the financial system was found to be quite high and this of course limits the effectiveness of interest rate transmission channel. This trend should be reversed to allow monetary policy instruments work efficiently through the various channels highlighted by this study thereby allowing both economies attain the desired level of economic stability.

\section{References}

Abradu-Otoo, P., Amoah, B., \& Bawumia, M. (2003). An investigation of the transmission mechanisms of monetary policy in Ghana: A structural vector error correction analysis. Bank of Ghana, Working Paper, No. 2.

Alexander, M. W. E., Enoch, M. C., \& Baliño, M. T. J. (1995). The adoption of indirect instruments of monetary policy: International Monetary Fund.

Anonymous. (n.d). Retrieved from https://www.cbn.gov.ng/MonetaryPolicy/Reforms.asp.

Central Bank of Nigeria. (2011). Understanding monetary policy series. 3(2), 13-19.

Central Bank of Nigeria. (2018). Statistical Bulletin, Central bank of Nigeria. 2(3), 20-23.

Ezeaku, H. C., Ibe, I. G., Ugwuanyi , U. B., Modebe, N. J., \& Agbaeze, E. K. (2018). Monetary policy transmission and industrial sector growth: Empirical evidence from Nigeria. Nigerian Journal of Banking and Finance, 12(1), 1-12.

FolaIwo, A. O., \& Osinubi, T. S. (2006). Monetary policy and macroeconomic instability in Nigeria: A rational expectation approach. Journal of Social Science, 12(2), 93-100.

$\mathrm{Fu}$, Q., \& Liu, X. (2015). Monetary policy and dynamic adjustment of corporate investment: A policy transmission channel perspective. China Journal of Accounting Research, 8(2), 91-109.

Jhingan, M. L. (2005). The economics of development and planning (38th ed.). India: New Delhi: Virade Publications (P) Ltd.

Kovanen, A. (2011). Monetary policy transmission in Ghana: Does the interest rate channel work?

Lucky, A., \& Uzah, C. (2017). Monetary policy transmission mechanisms and domestic real investment in Nigeria: A time series study 1981-2015. IIARD International Journal of Economic and Financial Management, 3(2), 29-59.

Mashat, R. A., Billmeier, A., \& Fund, I. M. (2008). The monetary transmission mechanism in Egypt (pp. 23-34). Rania al- Mashat and Andreas Billmeier Working Paper No. 411

Mishra, P. K., Das, J. R., \& Mishra, S. K. (2010). The dynamics of savings and investment relationship in India. European Journal of Economics, Finance, and Administration Sciences, 1(8), 164-172.

Modigliani, F., \& Miller, M. H. (1958). The cost of capital, corporation finance and the theory of investment. The American Economic Review, 48(3), 261-297.

Mugume, A. (2009). Monetary transmission mechanisms in Uganda. The Bank of Uganda, 4(1), 3-52.

Ncube, M. (2007). Financial systems and monetary policy in Africa (pp. 98-110). Economic Research Southern Africa Working Paper No. 20.

International Journal of Business Management and Finance Research

2021

DOI: $10.53935 / 26415313 . v 4 i 2.187$

Corresponding Author: Efanga Udeme Okon Email: Funding: This study received no specific financial support.

Article History:

Received: 6 September 202

Revised: 3 November 2021

Accepted: 22 November 202

Published: 29 December 2021

(C) 2021 by the authors; licensee Academic

Publishing Group
Onoh, J. K. (2007). Dimensions of monetary policy (3rd ed., pp. 121-123). Port-Harcort Nigeia: Sonite Publishers ltd.

Onwumere, J. U. J., Onodugo, V., \& Ibe, I. (2014). Financial structure and economic growth: Evidence from Nigeria. Global Journal of Management and Business Research, 13(5), 1-9.

Partachi, I., \& Mija, S. (2015). Monetary policy-instrument for macroeconomic stabilisation. Procedia Economics and Finance, 2(4), 485-493.

Quartey, P. (2010). Price stability and the growth maximizing rate of inflation for Ghana. Modern Economy, 1(03), 180-194.

Roe, A. R., \& Sowal, N. (1997). From direct to indirect monetary control in Sub-Saharan Africa. Journal of African Economies, 6(1), 212-264.

Sowa, N. K., \& Abradu-Otoo, P. (2007). Inflation management in Ghana - the output factor. Paper presented at the Bank of England/Cornell University Workshop on New Developments in Monetary Policy in Emerging Economies, London. 